\title{
Pengaruh Pertumbuhan Ekonomi Pada Sektor Industri, Pertanian, dan Perdagangan, Hotel dan Restoran Terhadap Jumlah Penduduk Miskin Di Wilayah Gerbangkertasusila Plus Pada Tahun 2015-2019
}

\author{
Diovany Anggoro, Sishadiyati, Muhammad Wahed \\ Universitas Pembangunan Nasional Veteran Jawa Timur \\ Email: Diovany125@gmail.com
}

\begin{tabular}{l}
\hline \hline Article Info \\
\hline Article history: \\
Published: Dec 28, 2021 \\
Page: $11-18$ \\
\hline
\end{tabular}

Keyword:

Sektor Industri; Sektor

Pertanian; Sektor

Perdagangan, hotel dan

restoran; Jumlah Penduduk

Miskin

Abstract
Penelitian ini bertujuan untuk menganalisis dan
menguji pengaruh pertumbuhan ekonomi pada sektor
industri, pertanian, dan perdagangan, hotel dan restoran
terhadap jumlah penduduk miskin di wilayah
Gerbangkertasusila Plus. Berdasarkan hasil penelitian
Sektor Industri, Pertanian, dan Perdagangan
berpengaruh negatif dan signifikan terhadap penurunan
Jumlah Penduduk Miskin di wilayah
Gerbangkertasusila Plus.

Kata kunci : Sektor Industri; Sektor Pertanian; Sektor Perdagangan, hotel dan restoran; Jumlah Penduduk Miskin

This study aims to analyze and examine the effect of economic growth in the industrial, agricultural and trade sectors, hotels and restaurants on the number of poor people in the Gerbangkertasusila Plus area. Based on the research results, the Industry, Agriculture, and Trade sectors have a negative and significant impact on the reduction in the number of poor people in the Gerbangkertasusila Plus area.

Keywords: Industrial Sector; Agriculture Sector; Trade, hotel and restaurant sector; Number of Poor Population

\section{Pendahuluan}

Permasalahan

pembangunan

meningkatkan Produk Domestik Bruto

(PDB), pendapatan dan menurunkan jumlah penduduk miskin. Kemiskinan merupakan salah satu masalah yang mendasar dan menjadi perhatian di tiap-tiap negara yang sedang berkembang. Kemiskinan juga tidak

\section{Editorial Office:}

Prodi Ilmu Ekonomi Fakultas Ekonomi dan Bisnis Islam, UIN Sunan Ampel Surabaya

Jl. Ahmad Yani 117 Surabaya, Jawa Timur 60237, Indonesia.

Email: oje@uinsby.ac.id 
hanya menjadi masalah nasional saja tetapi juga menjadi fokus utama dalam pembangunan di Provinsi Jawa Timur. Beberapa faktor yang mempengaruhi kemiskinan antara lain tingkat pendidikan masyarakat, pendapatan, pengangguran, geografis, karakter, sosial dan budaya, serta faktor lain yang mempengaruhi. Fenomena dapat di temukan dengan mudah hampir di setiap sudut wilayah, baik di pedesaan maupun perkotaan.

Tren angka kemiskinan tertinggi ada pada Kabupaten Bangkalan. Berdasarkan data Badan Pusat Statistik (BPS) Jawa Timur, jumlah angka kemiskinan Kabupaten Bangkalan dari tahun 2015-2019 mengalami penurunan. Sedangkan angka kemiskinan terendah pada Kota Mojokerto dengan jumlah angka kemiskinan pada tahun 2015 sebesar 7720 jiwa turun pada tahun 2019 sebesar 6630 jiwa (BPS).

Berdasarkan data fundamental makro ekonomi, pertumbuhan ekonomi Jawa Timur ditopang oleh tiga sektor utama yaitu Sektor Pertanian, Sektor Industri Manufaktur, Sektor Perdagangan, Hotel dan Restoran (BPS 2020). Meskipun tiga sektor tersebut merupakan penyumbang terbanyak dalam PDRB Jawa Timur, akan tetapi pekerjanya masih tergolong miskin. Jadi meskipun Sektor Pertanian, Industri dan Perdagangan termasuk dalam kategori sektor penyumbang terbanyak dalam PDRB yang dominan pekerjanya adalah petani, buruh dan karyawan swasta ini dirasa belum cukup untuk mensejahterahkan hidup mereka.

Berdasarkan hal tersebut, penelitian ini bertujuan untuk memahami lebih dalam setiap output sektoral dalam merespon jumlah penduduk miskin di Provinsi Jawa Timur, yang merupakan wilayah yang paling dinamis serta memiliki posisi penting dalam ekonomi dan merupakan Provinsi terbesar kedua di Indonesia. Berdasarkan latar belakang tersebut peneliti menyajikan rumusan masalah sebagai berikut : 1) Bagaimana pengaruh sektor industri terhadap jumlah penduduk miskin di Wilayah Gerbangkertasusila plus. 2) Bagaimana pengaruh sektor pertanian terhadap jumlah penduduk miskin di Wilayah Gerbangkertasusila plus. 3) Bagaimana pengaruh sektor perdagangan, hotel dan restoran terhadap jumlah penduduk miskin di Wilayah Gerbangkertasusila plus.

\section{Kajian Pustaka}

Pembangunan pada dasarnya merupakan proses multi dimensional yang meliputi perubahan struktur sosial, perubahan dalam sikap hidup masyarakat dan perubahan dalam kelembagaan/institusi nasional. Oleh karena itu, manusia berperan cukup besar dalam mewujudkan pembangunan ekonomi yaitu sebagai tenaga kerja, input pembangunan, dan konsumen hasil pembangunan itu sendiri. Pembangunan juga meliputi banyak hal seperti perubahan suatu tingkat pertumbuhan ekonomi, pengurangan ketimpangan pendapatan dan pengentasan kemiskinan.

Dalam kondisi yang ada saat ini, tingkat kemiskinan bukan hanya tentang rendahnya kualitas ekonomi, tapi juga dilihat dari sudut pandang yang berbedabeda dan tergantung pandangan yang digunakan maka batasan kemiskinan juga 
akan bergeser. Dalam arti luas kemiskinan merupakan ketidakmampuan ekonomi tidak sebatas pada belum mampu memenuhi kebutuhan dasar namun juga secara umum belum mampu memenuhi kebutuhan sandang, pangan dan papan (Alit dan Sudiana, 2013). Di Indonesia angka kemiskinannya tergolong masih sangat tinggi, meskipun BPS setiap tahunnya merilis data bahwa ada penurunan angka penduduk miskin di Indonesia. Meskipun jumlah penduduk miskin berkurang, adanya potensi untuk kembali naik juga tetap ada, apalagi sudah memasuki zaman global yang menuntut seseorang harus bisa bersaing dengan kemampuan yang dimiliki.

Sektor Industri Pengolahan merupakan salah satu dari sektor yang memiliki peranan penting dalam menunjang pertumbuhan nasional. Disisi lain kebanyakan negara menganggap bahwa sektor indistri pengolahan merupakan suatu motor penggerak bagi pertumbuhan ekonomi, karena mampu memberikan keuntungan yang besar dibandingkan dengan produk lainnya. Oleh karena itu strategi industrialisasi sering digunakan untuk mencapai kesejahteraan masyarakat. Menurut Dian Candra Sakti (2016) pada penelitiannya menyatakan bahwa sektor industri berpengaruh negatif dan signifikan terhadap penurunan jumlah penduduk miskin di Provinsi Jawa Timur. Sektor Pertanian merupakan salah satu sektor yang begitu produktif dan memiliki peranan penting dalam pertumbuhan ekonomi nasional. Hal seperti ini dapat dilihat dari kontribusinya dalam pemantapan ketahanan pangan, pengentasan kemiskinan, menciptakan lapangan pekerjaan, dan pemerataan pendapatan. Menurut Adelina Octavia Sihombing dan Rita Herawati Bangun (2019) pada penelitiannya menyatakan bahwa sektor pertanian berpengaruh negatif dan signifikan terhadap penurunan jumlah penduduk di Sumatera Utara. Jika aktifitas perdagangan internasional adalah ekspor dan impor, maka salah satu dari komponen tersebut atau kedua-duanya dapat menjadi motor penggerak bagi pertumbuhan ekonomi. Menurut Ananto Wibowo (2019) pada penelitiannya menyatakan bahwa sektor perdagangan memiliki pengaruh negatif dan signifikan terhadap penurunan jumlah penduduk miskin di Provinsi Kalimantan Tengah.

\section{Metode Penelitian}

Metode penelitian yang digunakan dalam penelitian ini adalah pendekatan kuantitatif. Data yang digunakan dalam penelitian ini adalah data sekunder. Data sekunder yaitu data yang diperoleh melalui media ataupun perantara secara tidak langsung yang berupa buku, catatan, bukti yang telah ada, atau arsip baik yang dipublikasikan maupun yang tidak dipublikasikan secara umum. Data sekunder tersebut bersumber dari BPS Jawa Timur dengan periode 2015-2019. Pendekatan kuantitatif pada penelitian ini menggunakan metode regresi data panel. Regresi data panel merupakan teknik analisis terhadap gabungan dari data time series (antar waktu) dan data cross section (antar individu/ruang). Penelitian ini dilakukan peneliti di Wilayah Gerbangkertasusila plus (Kota surabaya, Kabupaten Tuban, Kabupaten Lamongan, Kabupaten Bojonegoro, Kabupaten Gresik, Kabupaten Sidoarjo, Kabupaten dan Kota Mojokerto, Kabupaten Jombang, Kabupaten Bangkalan, Kabupaten dan Kota Pasuruan). Penelitian 
ini menggunakan variabel sektor industri, sektor pertanian, sektor perdagangan sebagai variabel independen (bebas) dan variabel jumlah penduduk miskin sebagai variabel dependen (terikat). Model dasar regresi data panel yang digunakan adalah sebagai berikut :

$$
\begin{aligned}
& Y_{i t}=\beta_{0}+\beta_{1} X_{1 i t}+\beta_{2} X_{2 i t}+\beta_{3} X_{3 i t} \\
& +u_{i t}
\end{aligned}
$$

Keterangan :

$\begin{array}{ll}\mathrm{Y}_{\text {it }} & \text { : Jumlah Penduduk Miskin } \\ \beta & : \text { Koefisien intersip } \\ \mathrm{X}_{1} & \text { : Sektor Industri } \\ \mathrm{X}_{2} & \text { : Sektor Pertanian } \\ \mathrm{X}_{3} & \text { : Sektor Perdagangan } \\ \mathrm{i} & \text { : Indikasi data cross section } \\ \mathrm{t} & \text { : Indikasi data time series }\end{array}$

\section{Hasil dan Pembahasan \\ Hasil \\ Hasil Regresi Common Effect Model (CEM)}

\begin{tabular}{|l|l|}
\hline R-squared & 0.520462 \\
\hline Adjusted R-squared & 0.494773 \\
\hline
\end{tabular}

Nilai Adjusted R-squared sebesar 0,494773 yang berarti bahwa variasi dalam variable independen dapat dijelaskan sebesar 49,47\% dari variable dependen

Hasil Regresi Fixed Effect Model (FEM)

\begin{tabular}{|l|l|}
\hline R-squared & 0.988393 \\
\hline Adjusted R-squared & 0.984781 \\
\hline
\end{tabular}

Nilai Adjusted $R$-squared sebesar 0,984781 yang artinya variasi dalam variable independen dapat dijelaskan sebesar 98,47\% dari variabel dependen. Hasil Regresi Random Effect Model (REM)

\begin{tabular}{|l|l|}
\hline R-squared & 0.202254 \\
\hline Adjusted R-squared & 0.159517 \\
\hline
\end{tabular}

Nilai Adjusted $R$-squared sebesar 0,159517 yang artinya variasi dalam variable independen dapat dijelaskan sebesar $15,95 \%$ dari variabel dependen.

\section{Hasil Uji Chow}

Hasil Uji Chow pada penelitian ini diperoleh hasil nilai Probabilitas Crosssection $\mathrm{F}$ sebesar 0,0000 yang memiliki nilai lebih kecil dari 0,05 maka dapat diartikan bahwa $\mathrm{H}_{0}$ ditolak. Sehingga dapat disimpulkan bahwa model Fixed Effect Model (FEM) merupakan model yang lebih tepat digunakan dibandingkan model Common Effect Model (CEM).

\section{Hasil Uji Hausman}

Hasil Uji Hausman pada penelitian ini diperoleh nilai probabilitas Chi-Square sebesar 0,0000 yang memiliki nilai lebih kecil dari 0,05 yang berarti hasilnya adalah menolak $\mathrm{H}_{0}$. Kesimpulannya adalah model Fixed Effect (FEM) lebih tepat digunakan dibandingkan dengan model Random Effect (REM). Berdasarkan dari hasil Uji Chow dan Uji Hausman dapat disimpulkan bahwa model yang paling tepat digunakan untuk penelitian ini adalah model Fixed Effect.

\section{Uji Hipotesis}

Ada atau tidaknya pengaruh simultan dari variabel independen Sektor Industri, Sektor Pertanian, dan Sektor Perdagangan, hotel dan restoran, dapat dilihat dengan menganalisisnya menggunakan $\mathrm{Uji} F$ dengan hipotesis sebagai berikut :

a) $\mathrm{H}_{0}: \beta_{1}=\beta_{2}=\beta_{3}=\beta_{4}=\beta_{5}=0$, artinya secara keseluruhan tidak ada pengaruh variabel independent $(\mathrm{X})$ terhadap variabel dependen $(\mathrm{Y})$.

b) $\mathrm{H}_{1}: \beta_{1} \neq \beta_{2} \neq \beta_{3} \neq \beta_{4} \neq \beta_{5} \neq 0$, artinya ada pengaruh secara simultan variabel independent $(\mathrm{X})$ terhadap variabel dependen (Y).

Pada nilai $F$ tabel dapat dilihat pada tabel $F$ statistik pada df $1=$ jumlah variabel- 
1 atau 3-1 = 2 dan df $2=n-k-1$ atau 70-2-1 = 67 (k adalah jumlah variable independen). Dengan signifikansi 0,05 diperoleh hasil $\mathrm{F}$ table $=3,13$.

Variabel sector Industry, Pertanian, dan Perdagangan, hotel dan restoran secara Bersama-sama berpengaruh terhadap Jumlah penduduk miskin. Hal ini dikarenakan nilai $\mathrm{F}$ hitung $>\mathrm{F}$ table $(273,7025>3,13)$ atau signifikansi $>0,05$ sehingga $\mathrm{H}_{0}$ diterima.

\section{Pengaruh secara parsial antara Sektor} Industri (X1) terhadap Jumlah Penduduk Miskin (Y).

Dilihat dari table 4.8 nilai koefisien regresi pada Sektor Industri yang diperoleh sebesar -9,544307, maka setiap kenaikan 1 (juta rupiah) pada sector industry dapat menimbulkan penurunan pada Jumlah penduduk miskin sebesar 9,544307.

\section{Pengaruh secara parsial antara Sektor} Pertanian (X2) terhadap Jumlah Penduduk Miskin (Y).

Dilihat dari table 4.8 nilai koefisien regresi Sektor Pertanian yang diperoleh sebesar -2,480991, maka setiap kenaikan 1 (juta rupiah) pada Sektor Pertanian dapat menimbulkan penurunan pada Jumlah Penduduk Miskin sebesar 2,480991.

\section{Pengaruh secara parsial antara Sektor} Perdagangan, hotel dan restoran (X3) terhadap Jumlah Penduduk Miskin (Y).

Dilihat dari table 4.8 nilai koefisien regresi Sektor Perdagangan, hotel dan restoran yang diperoleh sebesar -1,125772, maka setiap kenaikan 1 (juta rupiah) pada Sektor Perdagangan, hotel dan restoran dapat menimbulkan penurunan pada Jumlah Penduduk Miskin sebesar 1,125772.

\section{Pembahasan}

\section{Analisis Pengaruh Variabel Sektor Industri Terhadap Jumlah Penduduk Miskin}

Sektor Industri memiliki pengaruh negative dan signifikan terhadap penurunan Jumlah Penduduk Miskin. Maka setiap kenaikan 1 (juta rupiah) pada sector industry dapat menimbulkan penurunan pada Jumlah penduduk miskin sebesar 9,544307 orang. Ini menunjukkan bahwa intensitas tenaga kerja pada sector industry di wilayah Gerbangkertasusila Plus mampu menyerap tenaga kerja dengan tingkat keterampilan yang tinggi. Hal ini sesuai dengan hipotesis penelitian dimana Sektor Industri berpengaruh negatif dan signifikan terhadap Jumlah Penduduk Miskin. Hasil penelitian ini sesuai dengan penelitian yang dilakukan oleh Dian Candra Sakti (2016). Hal ini membuktikan bahwa intensitas tenaga kerja pada sector industri di wilayah Gerbangkertasusila Plus mampu menyerap tenaga kerja dengan tingkat keterampilan yang lebih tinggi.

Struktur perekonomian suatu wilayah yang relative maju dapat ditandai oleh semakin besarnya peran sector industry pengolahan dalam menopang perekonomian wilayah tersebut. Sektor Industri dianggap sebagai "The Leading Sector" yang bisan memacu berkembangnya beberapa sector yang lain, seperti sector pertanian maupun perdagangan (Arsyad dalam Amin 2015). 
Analisis Pengaruh Variabel Sektor Pertanian Terhadap Jumlah Penduduk Miskin

Sektor Pertanian memiliki pengaruh negatif dan signifikan terhadap penurunan Jumlah Penduduk Miskin. Maka setiap kenaikan 1 (juta rupiah) pada Sektor Pertanian dapat menimbulkan penurunan pada Jumlah Penduduk Miskin sebesar 2,480991 orang. Keadaan seperti ini membuktikan bahwa sector pertanian memiliki potensi untuk menjadi sector yang dapat diandalkan dalam penanggulangan jumlah penduduk miskin di wilayah Gerbangkertasusila Plus. Hal ini sesuai dengan hipotesis penelitian dimana Sektor Pertanian berpengaruh negatif dan signifikan terhadap Jumlah Penduduk Miskin. Hasil penelitian ini sesuai dengan penelitian yang dilakukan oleh Adelina Octavia Sihombing dan Rita Herawati Bangun (2019). Hal ini membuktikan bahwa Sektor Pertanian memiliki potensi untuk menjadi salah satu sektor yang dapat diandalkan dalam penurunan jumlah penduduk miskin di wilayah Gerbangkertasusila Plus.

Pada negara berkembang hampir seluruh studi memberikan dukungan empiris mengenai pandangan sector pertanian yang telah menjadi pendorong utama pengurangan kemiskinan. Kondisi penduduk dilihat dari sectoral Sebagian besar penduduk miskin di wilayah Gerbangkertasusila Plus bekerja disektor pertanian $33 \%$ rumah tangga termiskin diwilayah Gerbangkertasusila Plus mengandalkan kehidupan dari sector pertanian. Dan sebaliknya, 5\% dari rumah tangga terkaya mengandalkan kehidupan dari sector ini.

\section{Analisis Pengaruh Variabel Sektor Perdagangan, hotel dan restoran Terhadap Jumlah Penduduk Miskin}

Sektor Perdagangan, hotel dan restoran memiliki pengaruh negatif dan signifikan terhadap penurunan Jumlah Penduduk Miskin. Maka setiap kenaikan 1 (juta rupiah) pada Sektor Perdagangan, hotel dan restoran dapat menimbulkan penurunan pada Jumlah Penduduk Miskin sebesar 1,125772. Pada literatur ekonomi telah menunjukkan bahwa keterbukaan perdagangan adalah kunci pengurangan kemiskinan. Secara umum, sector perdagangan memengaruhi pendapatan orang miskin melalui berbagai alternatif seperti efek dari pertumbuhan ekonomi, pergerakan harga-harga, stabilitas makro dari pendapatan pemerintah. Hal ini sesuai dengan hipotesis penelitian dimana Sektor Perdagangan, hotel dan restoran berpengaruh negatif dan signifikan terhadap Jumlah Penduduk Miskin. Hasil penelitian ini sesuai dengan penelitian yang dilakukan oleh Ananto Wibowo (2019). Besarnya pengaruh dari sector pertanian terhadap penurunan jumlah penduduk miskin dibandingkan oleh sector perdagangan, hotel dan restoran, menunjukkan adanya perubahan transformasi sectoral di wilayah Gerbangkertasusila Plus.

\section{Kesimpulan}

Berdasarkan hasil penelitian ini dapat disimpulkan bahwa Sektor Industri memiliki pengaruh negatif dan signifikan terhadap penurunan Jumlah Penduduk Miskin di 
wilayah Gerbangkertasusila Plus Periode tahun 2015-2019. Dengan nilai koefisien regresi pada Sektor Industri yang diperoleh sebesar -9,544307, maka setiap kenaikan 1 juta rupiah pada sector industry dapat menimbulkan penurunan pada Jumlah penduduk miskin sebesar 9,544307 di wilayah Gerbangkertasusila Plus.

Sektor Pertanian memiliki pengaruh negatif dan signifikan terhadap penurunan Jumlah Penduduk Miskin di wilayah Gerbangkertasusila Plus Periode tahun 2015-2019. Dengan nilai koefisien regresi Sektor Pertanian yang diperoleh sebesar 2,480991, maka setiap kenaikan 1 juta rupiah pada Sektor Pertanian dapat menimbulkan penurunan pada Jumlah Penduduk Miskin sebesar 2,480991 di wilayah Gerbangkertasusila Plus. Sektor Perdagangan, hotel dan restoran memiliki pengaruh negatif dan signifikan terhadap penurunan Jumlah Penduduk Miskin di wilayah Gerbangkertasusila Plus Periode tahun 2015-2019. Dengan nilai koefisien regresi Sektor Perdagangan, hotel dan restoran yang diperoleh sebesar -1,125772, maka setiap kenaikan 1 juta rupiah pada Sektor Perdagangan, hotel dan restoran dapat menimbulkan penurunan pada Jumlah Penduduk Miskin sebesar 1,125772 di wilayah Gerbangkertasusila Plus.

\section{Saran}

Perlu adanya perhatian khusus dari pemerintah pada perkembangan pada sector industry, pertanian, dan perdagangan, hotel dan restoran. Terutama pada sector industry yang memiliki potensi yang tinggi dalam menurunkan jumlah penduduk miskin. Sedangkan pada sector pertanian dan sector perdagangan, hotel dan restoran diharapkan potensinya lebih dikembangkan lagi terhadap penyerapan tenaga kerja dan juga potensi dari tenaga kerjanya harus lebih baik lagi. Sehingga dapat menurunkan jumlah penduduk miskin di wilayah Gerbangkertasusila Plus.

\section{Daftar Pustaka}

Afandi, A. G., \& Soesatyo, Y. (2012). Pengaruh Industri Pengolahan, Perdagangan, Hotel, Dan Restoran, Dan Pertanian Terhadap pdrb Kabupaten Mojokerto. Univestitas Negeri Surabaya.

Alit, Wiradyatmika A.A. Gde dan Ketut Sudina. 2013. Pengaruh Jumlah Penduduk, Jumlah Penyerapan Tenaga Kerja dan Pengangguran Terhadap Jumlah Penduduk Miskin di Kabupaten Buleleng. Jurnal Ekonomi Pembangunan, Fakultas Ekonomi dan Bisnis Universitas Udayana.

Amin, Ayu Azhari. (2015). Peran Sektor Industri Pengolahan Terhadap Perekonomian dan Penyerapan Tenaga Kerja Di Provinsi Sulawesi Utara. Jurnal Ilmiah Fakultas Pertanian Universitas Sam Ratulangi Manado, 121.

Dzunurain, Ahmad,. (2014). Pengaruh Profitabilitas Dan Ukuran Perusahaan Terhadap Pengeluaran Zakat Pada Bank Umum Syariah Di Indonesia Tahun 2010-2013. Universitas Pendidikan Indonesia.

Horizons, S., Myers, F., Analysis, C. P., Hayes, A. F., Hayes, Hayes, A. F., Field, A., Help, F., Duffy, D. L., Hsu, 
Y., Serpell, J. A., Collier, S., Matthews, A. E., Klimov, P. B., Proctor, H. C., Dowling, A. P. G., Diener, L., Hager, S. B., ... Wennberg, J. E. (2018). Pengaruh Sektor Pertanian Dan Sektor Perdagangan Terhadap Produk Domestik Regional Bruto (Pdrb) Kabupaten Pringsewu Periode 20082016 Dalam Perspektif Ekonomi Islam. Journal of Business Ethics.

Jayadi, D. S., \& Brata, A. G. (2016). Peran Pertumbuhan Ekonomi Dalam Menurunkan Kemiskinan di Tingkat Provinsi di Indonesia Tahun 2004-2012. MODUS.

https://doi.org/10.24002/modus.v28i1.6 69

Jhingan, M. L. (2007), Ekonomi Pembangunan dan Perencanaan. Jakarta : Raja Grafindo Persada.

Niara, A., \& Andria, Z. (2019). Pengaruh Kontribusi Sektor Pertanian dan Industri Terhadap Kemiskinan Di Kabupaten Aceh Utara. Jurnal Ekonomi Regional Unimal.

Prasetyo, S. (2019). Pusat Strategi Dan Layanan Ekonomi Maslahat (Satrya Emas) Melalui Ekonomi Kreatif Di Kabupaten Pasuruan. Journal of Public Administration.

Sakti, D. C., \& Berachim, B. (2016). Pengaruh Output Sektor Pertanian, Industri Pengolahan dan Perdagangan Terhadap Jumlah Penduduk Miskin di Propinsi Jawa Timur ( Tahun 2005 2013 ). Jurnal Ekonomi dan Bisnis.

Sihombing, A. O., \& Bangun, R. H. (2019). Analisis Korelasi Sektor Pertanian
Terhadap Tingkat Kemiskinan di

Provinsi Sumatera Utara. JURNAL AGRICA.https://doi.org/10.31289/agric a.v12i1.2220

Sriyana, J. (2014). Metode Regresi Data Panel. Yogyakarta : Ekonesia

Sukirno, Sadono. (2010). Makroekonomi Teori Pengantar Edisi Ketiga, Jakarta : PT Raja Grafindo Persada.

Sukirno, Sadono. (2011). Makroekonomi Teori Pengantar, Jakarta : Grafindo Persada.

Surya Ayomi. (2014). Analisis Pengaruh Pertumbuhan Sektor Utama Terhadap Tingkat Kemiskinan, Tingkat Pengangguran, Dan Indeks Pembangunan Manusia (Ipm) Di Satuan Wilayah Pembangunan Madiun Dan Sekitarnya Tahun 2003-2012. Jurnal Ilmiah.

Wibowo, A. (2019). Pengaruh Output Sektor Pertanian Dan Perdagangan Terhadap Kemiskinan Di Provinsi Kalimantan Tengah. Jurnal Riset dan Aplikasi Matematika (JRAM). https://doi.org/10.26740/jram.v3n2.p89 $-100$ 